above-described method are invalidated, or liable to be invalidated, by leakage of air into the vacuum pump. This is not the case if due precautions are taken. The pump must be in such good order that no appreciable leakage occurs when it is left vacuous for several days, and it must be kept vacuous for a week or more before use, for if air be left in it a small amount attaches itself to the glass walls of the apparatus and only escapes slowly when the pump is made vacuous again. Air likewise attaches itself to the walls of the boiling flask, but it is got rid of by the preliminary boiling of the dilute acid previous to the introduction of the oil. In all analyses of gases, whether in oil, water, or salt solutions, such a preliminary boiling was invariably adopted, and by taking these precautions many hundreds of analyses have been made without invalidation of results by leakage of air. I have elsewhere ${ }^{9}$ recorded nearly a hundred analyses of the gases in sea water, and the mean nitrogen values then obtained are almost identical with the nitrogen absorption values determined by Dittmar.

The bearing of the above recorded results upon many phases of caisson disease is probably a direct one. The commonest symptoms observed in caissoniers consist of joint and muscular pains, and in paralysis, the latter being the result of injury to the spinal cord. Thus in necropsies on caissoniers Bert observed softening of some inches of the spinal cord in the dorsal region. Von Leyden, in a case of death 15 days after decompression, observed signs of myelitis and small irregular fissures in the mid-dorsal cord, probably produced by the escape of gas. Necropsies on divers have shown necrobiosis and hæmorrhages in the spinal cord ${ }^{10}$ and distension of the blood-vessels by air bubbles. ${ }^{11}$

Chemical analysis shows that spinal cord and peripheral nerves contain nearly 20 per cent. of fat and fat-like sub. stances. Adipose tissue contains about 83 per cent. of fat, and yellow bone marrow (as distinct from red marrow, which is poor in fat) contains no less than 96 per cent. of at (Gorup-Besanez). If these tissues were saturated with aitrogen at, for instance, four atmospheres of atmospheric pressure, 100 cubic centimetres of them would contain, instead of the $0.975 \times 4=3.90$ cubic centimetres of dissolved nitrogen present in an equal volume of water, about 7 cubic centimetres in the case of the spinal cord and nerve and 20 cubic centimetres in the case of yellow bone marrow. On sudden decompression, therefore, the volume of nitrogen bubbling off in a gaseous form might be from two to six times as much as that from the non-fatty fluids and tissues of the body.

It has been found that the severity of the symptoms developed by caissoniers is influenced greatly by the time of exposure to increased pressure. In sinking the foundations of a bridge at St. Louis a pressure reaching at a maximum to 50 pounds above normal was used and a large proportion of the workers were affected. As the depth of the caissons increased the shifts were shortened from four hours to one hour, with the result that the serious accidents were reduced to nil. ${ }^{12}$ Presumably, therefore, the body tissues were not so fully saturated with nitrogen in the shorter as in the longer period. On the other hand, Hill and Greenwood ${ }^{13}$ found that on exposing themselves to a pressure of from 30 to 45 pounds their urine became saturated with the theoretical amount of nitrogen in from 10 to 15 minutes. This quicker saturation must be due to the blood-flow through the kidney being much more rapid than that through the spinal cord, and very much more rapid than that through adipose tissues. Even if it were as rapid through fat-containing tissues as through the kidney, the fats, in virtue of their greater solvent power, would take longer to become fully saturated than the fluids of non-fatty tissues.

Conclusion.-At body temperature fats dissolve more than five times as much nitrogen as an equal volume of water or blood plasma. The special tendency of the fat-containing tissues (such as subcutaneous tissues, spinal cord, and peripheral nerves) of caisson workers and divers to suffer injury from the liberation of gas bubbles after rapid decompression is dependent on this great solubility.

oxford.

9 Vernon : Journal of Physiology, vol. xix., p. 68, 1895 10 Cited by Hill and Macleod: Journal of Hygiene, rol. iii., pp. 408 and $499,1903$.

11 Hill : Recent Advances in Physiology, p. 250, 1906.

12 Paul Bert: La Pression Barométrique, p. 404, Paris, 1878.

13 Hill and Greenwood: Proceedings of the Royal Society, vol. Ixxix. B, p. 2l, 1907 .

\section{A CASE OF SELF-INDUCED (?) ABORTION.}

\author{
By A. B. M. THOMSON, M.B., Сh.B. EdiN.
}

THE occurrence of foreign bodies in utero is not so frequent as one might expect. Hellier ${ }^{1}$ accounts for 127 cases in literature and records one of his own. As an additional case and also for its medico-legal interest the following is worthy of record.

The patient, a married II.-para, aged 30 years, was first seen on the evening of June 26th, 1906. Her illness was attributed to a hearty meal of fish, of which she had partaken a few days before. She had a history of persistent pain in the abdomen and vomiting; incidentally it was mentioned that she had aborted. The product of abortion had been disposed of, but I was assured that "everything had come away." The peculiar odour of a purulent postpartum discharge was distinctly noticeable in the room. The patient's temperature was $102^{\circ} \mathrm{F}$; her pulse was 130 , small, and running; in addition she had the icteric tint and the apathy which are associated with septicæmia. Her abdomen was slightly distended, tympanitic, and tender, more especially in its lower part. On examination per vaginam a thin rod was found projecting for about 1 inch beyond the patulous os. Considering the gravity of the case I asked my colleague, Dr. John McDonald, to see the patient in consultation, to which request he very kindly acceded. When we removed the foreign body it was found to be an ordinary bone penholder, 4 inches in length, the rounded and pointed end of which had been introduced into the cavity of the uterus. The patient, although vague in her other statements, maintained repeatedly that she herself had induced the abortion. She died on the morning of the 27th, just 12 hours after being first seen.

Necropsy.-The brain was normal. The left lung was emphysematous and the pleura was adherent along the lateral border of the chest wall, evidently the result of a past pleurisy. On opening the abdomen the bowel was found distended with flatus; there was no evidence of peritonitis either general or pelvic, although a few loops of small intestine lying in the pouch of Douglas were red and injected. The spieen was much enlarged and semi-diffluent so that its removal intact was a work of some difficulty; it weighed 28 ounces. Before dissecting out the organs of generation en masse it was noted that the uterus was moveable and enlarged. There was a purulent discharge coating the walls of the vagina, but there was no sign of laceration. The uterus measured 6 inches in length, $4 \frac{1}{2}$ inches in breadth at the fundus, 2 inches in depth, and its walls were 3 inch in thickness. The os was patulous but without trace of any recent wound. On opening the uterus the placenta was found on its posterior wall; it was greenish at the margins with a dark, punctured wound in its centre. The end of the penholder fitted into this wound in the placenta. The left ovary contained a corpus luteum. The size of the uterus confirmed the patient's previous statement that she was between the third and fourth month of pregnancy.

The question which called for decision was whether this was in reality a case of self-induced abortion. Is it possible for a woman to introduce into her uterus, without causing injury to the vaginal walls or to the os, a straight rigid rod four inches in length? The only answer one could give was that in this case it was possible but very improbable. There was no condition present, such as prolapse, which would have rendered the introduction of the rod easier. If the patient herself introduced the penholder she must have become an adept, because there was no trace of violence having been used to insert it into the proper axis of the uterus, which was normal. On the supposition that this case was self-induced, another interesting point arises. The penholder had been left in utero to act as a bougie. This is unusual in cases of instrumental criminal abortion. The object, as a rule, is simply to "draw blood" from the uterus, and rarely is the instrument left in situ.

Perhaps, in conclusion, I may be permitted to express the opinion that instrumental criminal abortion is fairly frequent, judging from the number of cases of septic 
incomplete abortion one sees; and that, undoubtedly, many of them are self-induced.

Clapton Park, N.E.

Erratum.-In Dr. Alexander Morison's paper on the Nature and Management of Hypertrophy of the Heart, published in The LANCET of August 24th, p. 506, column 2, line 8 , the words "diminishing hypertrophy" should be "initiated hypertrophy," and on p. 508, column 11 , line 2, the word "rib-cartilages" should read " ribs and cartilages."

\section{A}

oF

\section{HOSPITAL PRACTICE, BRITISH AND FOREIGN.}

Nulla autem est alia pro certo noscendi via, nisi quamplurimas et morborum et dissectionum historias, tum aliorum tum proprias collectas habere, et inter se comparare-Morgagni De Sed. et Caus. Morb., lib. iv., Procmium.

\section{EAST LONDON CHILDREN'S HOSPITAL, SHADWELL, E.}

A CASE OF DOUBLE DEPRESSED FRACTURE OF THE SKULL AND PNEUMOTHORAX.

(Under the care of Mr. W. H. BowEN.)

FOR the notes of the case we are indebted to Dr. W. Norman May, resident medical officer.

A boy, aged 15 years, was admitted to hospital on August 2 nd at 7.30 A.M., the history being that about half an hour previously he had fallen off his bicycle and that the wheels of a van had passed over his head. He was unconscious and cyanosed with feeble running pulse and stertorous breathing. Fractures could be felt in both parietal regions, the one on the left side being more anteriorly placed than that on the right and not quite so near the vault of the skull. There was paralysis of the right arm and the right leg and the pupils were unequal. Some bruising was noticed, as if made by a wheel, over the first, second, and third ribs on both sides below the clavicles.

As the boy's condition was extremely serious he was immediately taken to the theatre and operated on by the resident medical officer. An incision over the left parietal region showed a depressed fracture over the motor area, the depressed fragment being triangular in shape, $2 \frac{1}{2}$ inches in length, and 1 inch in width at its base, which was formed by the fronto-parietal suture, the fracture extending through the centre of the parietal bone. The fragment was depressed beneath the surrounding bone, which overlapped it at its edges, and it was not until the fragment had been trephined at its border that it could be elevated and removed. The dura mater underneath appeared to be uninjured, while the fracture could be felt to continue down into the left temporal region but was not depressed there. An incision over the right parietal region showed a depressed fracture, guttershaped and running in a longitudinal direction, rather above the centre of the parietal bone. This was also trephined and the bone elevated, but there was no fragment broken off. The fracture conld be felt to extend down into the right mastoid region but with no depression. The incisions were sewn up with salmon.gut sutures and the patient was sent back to bed, the operation having taken about 25 minutes. The patient's breathing became much better after the fragment on the left side had been elevated and an anæsthetic became necessary to complete the operation. A few hours later the patient recognised his friends and spoke to them, also asking for things he wanted, while the movements in the right arm and leg returned, although the right arm was still weak. His breathing was very rapid and the alm nasi were noticed to be working, so his chest was examined again. On the right side there was a tympanitic note on percassion and the breathing was most markedly bronchial in character; the heart was displaced to the left and there was some emphysema at the root of the neck. An exploring syringe put into the right side of the chest confirmed the diagnosis of pneumothorax. The patient's breathing gradually became worse and he died at $9.30 \mathrm{~A}$ M. the following morning, 26 hours after the accident, apparently entirely from his lung trouble, as he was quite conscious up to the end and there were no paralyses of any kind.

Neoropsy - A post-mortem examination made on the following day showed the trephine holes as made at the operation, with the dura mater intact and normal and the brain uninjured and with no trace of hæmorrhage, lacera. tion, or contusion. The fracture on the left side extended down into the temporal fossa and involved the roof of the orbit to a very slight extent, while on the right side the fracture just reached down to the mastoid process, but there was no effusion of blood or depression of bone on either side. The right lung was collapsed and on opening up the trachea it was found that the right bronchus was torn completely across immediately below the bifurcation of the trachea, the torn ends being separated for half an inch. The rest of the structures at the root of the lung were uninjured; there was no blood in the pleural cavity and the ribs, clavicles, and pleuræ were quite intact.

Remarks by Dr. MAY.-The occurrence of these two interesting lesions in one case-namely, an apparently recoverable double depressed fracture of the skull and a pneumothorax caused by complete rupture of the bronchus without any injury to the ribs-seems to render this case worth recording. For permission to publish it I am indebted to Mr. Bowen, under whose care the patient was.

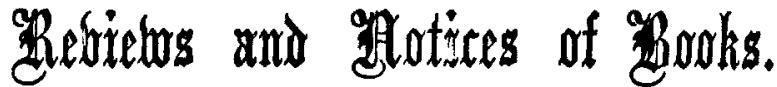

Epilepsy: A Study of the Idiopathic Disease. By WILLIAM Aldren TurNer, M.D. Edin., F.R.C.P. Lond., Physician to Out-patients at the National Hospital for the Paralysed and Epileptic, Queen's-square, and King's College Hospital, London; Visitiog Physician to the Colony for Epileptics, Chalfont St. Peter, \&c. London: Macmillan and Co., Limited. 1907. Pp. 272. Price 10s. net.

As a special monograph on the subject of idiopathic epilepsy Dr. Aldren Turner's book leaves little to be desired. It is a careful study of the disease chiefly from the clinical standpoint, with some interesting and important observations on its pathology contributed by Dr. John Turner of the Essex County Asylum. At the outset Dr. Aldren Turner premises that he regards epilepsy as an organic disease of the brain and that the morbid conditions which produce the convulsions eventually progress to those underlying the permanent dementia. After an introductory chapter he devotes two chapters to the etiology of the disease, in which he gives an exhaustive critical study of his own statistics and those of other authorities in regard to the causation of epilepsy. As a result he concludes that the proportion of epileptics in the general population is about 2 per 1000, that there is a slight preponderance in the male sex, and that the most important predisposing causes are ancestral epilepsy and neuropathic predisposition, which are found in about 50 per cent. of the cases.

In regard to the age incidence he finds that at least three. fourths of the cases arise under the age of 21 years and that the greatest number of cases commencing in any one year is to be found in the first year of life. The so-called stigmata of degeneration are found to be very commonly present in the subjects of epilepsy, especially in those cases commencing early in life. A careful analysis is given of the supposed determining canses of the convulsions such as the effect of various physiological, psychical, and pathological processes or their development, among them sleep, fright, trauma, and alcoholism. The general conclusion arrived at is that in those who bave inherited the epileptic tendency a convulsive habit may be established either in the course of natural development or as a result of certain occasional or accidental causes. Two chapters follow on the clinical features of epileptic fits and in these Dr. Aldren Turner largely follows the descriptions of Herpin, whose law he enunciates as follows: "That although" 